\title{
ARTÍCULOS
}

\section{ETNOGRAFÍA DE UNA AUSENCIA. LOS SENTIDOS DE LA FOTOGRAFÍA FAMILIAR EN LA TRANSMISIÓN DE LA MEMORIA TRAUMÁTICA}

\author{
ETHNOGRAPHY OF AN ABSENCE. THE MEANINGS OF FAMILY \\ PHOTOGRAPHY IN THE TRANSMISSION OF TRAUMATIC MEMORY
}

Jorge Moreno Andrés ${ }^{1}$

Universidad Nacional de Educación a Distancia (UNED)

Recibido: 19 de junio de 2019; Aprobado: 5 de abril de 2021.

\begin{abstract}
Cómo citar este artículo / Citation: Moreno Andrés, Jorge. 2021. «Etnografía de una ausencia. Los sentidos de la fotografía familiar en la transmisión de la memoria traumática». Disparidades. Revista de Antropología 76(2): e023. doi: <https://doi.org/10.3989/ dra.2021.023>.
\end{abstract}

RESUMEN: ¿Cómo se mueven las fotografías familiares dentro del espacio doméstico? ¿Qué ocurre cuando esas imágenes pertenecen a las víctimas del franquismo? El artículo examina los usos intergeneracionales que sufren esas imágenes y que permiten analizar la transmisión de la memoria familiar en un contexto traumático. Esto se realiza a partir del estudio de un caso paradigmático: el de la familia de Emilio Silva, fundador de la Asociación para la Recuperación de la Memoria Histórica. Será precisamente una fotografía familiar escondida en la rendija de la pared la que impulse a Emilio a reconstruir la historia de su abuelo, algo que fortuitamente desencadenará con el inicio del movimiento memorialista en España.

PALABRAS CLAVE: Fotografía; Antropología de la violencia y el sufrimiento social; Antropología visual; Duelo; Desapariciones; Guerra Civil española.

ABSTRACT: How do family photographs move in the domestic space? What happens when those images belong to victims of Franco's regime? This article examines the intergenerational uses and displacements of these images, enabling us to analyze both the transmission and silencing of familiar memories within a traumatic context. This article picks the paradigmatic case of Emilio Silva, founder of the Association for the Recovery of Historical Memory. The analysis focuses on two moments: the disappearance of Emilio's grandfather in 1936 and the encounter of the grandson with his remains in the grave, decades later. We shall see these two moments linked to different photographic manipulations, marking the temporal space where the various relationships of the family with the photographs take place. Indeed, a family photograph hidden in the wall of the house will impel Emilio Silva to reconstruct his grandfather's history, fortuitously triggering the beginning of the memorialist movement in Spain.

KEYWORDS: Photography; Anthropoology of Violence and Social Suffering; Visual Anthropology; Mourning; Disappearances; Spanish Civil War.

1 Correo electrónico: jorgemorenoandres@hotmail.com. ORCID iD: <https://orcid.org/0000-0002-9070-6343 >. 
"Una fotografía también es una pregunta» Emilio Silva

Dos años antes de que Emilio Silva² se decidiera abrir la fosa de Priaranza del Bierzo, aquella donde estaban los restos de su abuelo y con la que se inicia en España el llamado movimiento memorialista, su intención había sido más sencilla: él estaba dispuesto a escribir una novela. Un libro en el que dos exiliados regresaban después de muchos años a Pereje, el pueblo de su familia. La portada de esta ficción sería sin embargo una fotografía real, concretamente aquella que su abuela Modesta escondió durante la dictadura en la rendija de una pared. En esa fotografía, que conserva en la actualidad las marcas de haber estado doblada y oculta durante mucho tiempo, se muestra a un grupo de personas manifestándose en los años treinta contra el gobierno de la CEDA ${ }^{3}$. «Debió de ser la gran manifestación de Villafranca durante la Segunda República», señala Emilio. "Ahí está toda la izquierda de entonces pasando por un puente. Mi padre aparece con una pancarta que dice: Queremos un grupo escolar. Viva Azaña»"

En todas las familias hay siempre miembros que son custodios de la memoria del grupo. Cuando estos mueren desaparece el sentido que articulaba los objetos bajo su presencia. Es decir, los objetos, las fotografías, no funcionan sin cierta narrativa, y al morir quien los custodia quedan separados del orden que tenían. El cierre del acontecimiento vital dispara la narrativa de unos objetos que pueden ser organizados en otra historia, en otro relato diferente. En el caso de Emilio, lo que activa la escritura de una novela modulada en torno a una imagen familiar, era precisamente la muerte de su abuela Modesta ocurrida un año antes de tomar esa decisión. "Yo dejo un trabajo en 1998 para escribir una novela que es por lo que yo me pongo a buscar. [...] Y esa foto para mi [...] de hecho tengo que tener algún canutillo con la novela donde esa foto es la portada. O sea para mi era la portada de esa historia. Y el vínculo que yo rehago o establezco con mi abuela tiene que ver con eso".

2 Emilio Silva Barrera. Fundador de la Asociación para la Recuperación de la Memoria Histórica.

3 Confederación Española de Derechas Autónomas.

4 Entrevista realizada a Emilio Silva (Madrid, 22/12/2016). En adelante, todas las citas sin referencia explícita a un autor corresponden a fragmentos de esta entrevista.
Si la muerte activa la narrativa, la foto anima a la aventura, a la búsqueda. "La foto, de por sí, no es animada», señalaba Roland Barthes, "pero me anima: es lo que hace toda aventura» (1989:50). La fotografía anima a Emilio a escribir el relato, lo anima a la búsqueda, iniciando con ello una investigación que terminará con el descubrimiento del lugar donde enterraron a su abuelo: "Al hombre al que yo voy a ver, y que me lleva a la fosa de mi abuelo, yo lo voy a ver en realidad para que me cuente cosas que yo voy a meter en esa historia. No la van a cambiar, la van a ambientar. $Y$ en esa historia ya hay un entierro de esa fotografía ¿no?, para conservarla. [...] La escena es la de un niño que se despierta de noche y ve como su madre está escondiendo unas cosas, y está esa foto, y hablo de la foto de Azaña».

El análisis de la vida social de aquella fotografía de la manifestación, así como de otras imágenes que guardaba la familia, será precisamente lo que nos permita entender el desplazamiento y la transformación de unos objetos que, disimulados y vividos en el ambiente privado durante la dictadura franquista, transitarán al espacio público en los albores del siglo XXI provocando sin pretenderlo el surgimiento de un movimiento que cambiaría la historia de un país. En este sentido, la elección de Emilio Silva como caso de estudio ${ }^{5}$ se debe no solo a la importancia que tuvieron las fotografías familiares de esta persona en la exhumación de la fosa de Priaranza del Bierzo, sino también por tratarse de un caso paradigmático del tipo de vida que han tenido algunas imágenes de personas asesinadas por el régimen franquista. Pues las trayectorias que tuvieron estas fotografías en su salida del espacio privado al espacio público marcarán el camino que tendrán después otras imágenes similares.

Dos preguntas son fundamentales en este punto: ¿qué nos tiene que decir este tipo de materiales sobre la memoria de las víctimas del franquismo? y por otro lado ¿cómo «hacer hablar» a una fotografía desde un punto de vista antropológico? Con relación a la primera pregunta, debemos pensar que si la

5 Este estudio supone la continuidad de un trabajo de campo de larga duración que he realizado en la zona de Ciudad Real basado en la relación entre fotografía familiar y violencia política, y cuyo resultado principal es el libro El duelo revelado. La vida social de las fotografías familiares de las víctimas del franquismo, editado por el CSIC en el año 2018. 
desaparición del cuerpo hace cada vez más borrosa la figura del desaparecido, la fotografía se encarga de recordarnos la medida exacta del cuerpo que tenía, de aquella mirada que sin la imagen uno terminaría olvidando. Por eso las familias eligen las fotografías, cuando existen, como lugar donde seguir hablando con los muertos, pues la nitidez del retrato se percibe como el lugar donde las conversaciones con el ausente son precisamente más nítidas, más transparentes, un camino directo hacia lo que ya no está (Moreno Andrés 2018). En ese sentido el análisis sobre el uso familiar de las fotografías busca en realidad problematizar la relación con la ausencia, la relación con un tipo de seres ausentes que no solo aparecen cuando se abren las fosas, sino que han estado presentes durante décadas en las casas familiares. Esa vida en el subtierro (Ferrándiz 2011) se puede rastrear en los usos de las imágenes, las cuales objetivan en unos casos el esfuerzo por ocultar una memoria problemática e incómoda y en otros el esfuerzo por exponer de manera constante una memoria que da sentido a la familia. En cualquiera de los casos, analizar esas pragmáticas se vuelve fundamental para entender la transmisión de la memoria, algo que repercute en el vínculo que con las víctimas tenga la familia en la actualidad.

Por otro lado, y con relación a la pregunta sobre cómo «hacer hablar» a una fotografía, hago un análisis de las imágenes sustituyendo la idea de que la semiótica se funda en la existencia de un código por la idea de que se origina en la existencia de un interpretante. No me interesa, por tanto, el referente como problema significativo en semiótica, pues la mayoría de los procesos semióticos que producimos no tienen un referente, no hay referente en ellos; lo que hay son objetos que se construyen a partir de interpretaciones. Como veremos más adelante, en la acción de una mujer que esconde la fotografía de su marido asesinado lo que el objeto evoca no es solo al padre, es también el miedo y el dolor de ella, y lo que fundamenta el acento del etnógrafo es la interpretación de la acción de esa mujer, así como la de los herederos de la imagen (Moreno Andrés 2018). El estudio de esas pragmáticas, analizadas tras un trabajo de campo basado en observación y entrevistas, sitúa el movimiento espacial y temporal de la imagen como elemento central de la búsqueda de sentido, algo que exploro a partir de tres variables. Por un lado, el tiempo inscrito en el movimiento que desplaza la fotografía y que lleva a preguntarnos por las diferentes ubicaciones por las que ha transitado así como por las personas que la poseen, la heredan o la entregan. Por otro lado el tiempo inscrito en las historias que se cuentan cuando se mira una imagen. Y por último, el tiempo inscrito en la materialidad del objeto mismo y que lleva a preguntarnos por los usos que se le ha dado a la fotografía.

Para analizar ese ciclo vital donde las fotografías han ido practicándose, dialogo con los estudios más recientes sobre fotografía y antropología, aquellos que nos indican la necesidad de abordar la visualidad y materialidad de las imágenes en diálogo con el contenido de la fotografía, así como con los contextos reales donde los objetos están hechos para significar de una determinada manera (Edwards y Hart 2004: 6). Este enfoque de contenido/contexto se engarza con los recientes avances en Antropología Social (Banks y Morphy 1997; Edwards y Hart 2004; Miller 1987; Poole 1997; Porto 2004), en los cuales el "giro material» es visto como pertinente y sumamente importante para el estudio de las fotografías como agentes activos (Gell 1998) en la construcción social del significado. Al trazar la biografía del objeto (Kopytoff 1986), así como los sistemas visuales y materiales en los cuales funcionan las imágenes (Porto 2004), esperamos evidenciar la relación dialéctica que tienen las fotografías de los represaliados en los procesos de construcción de la memoria individual y colectiva. Al poner en diálogo las cualidades visuales y materiales de las fotografías, este estudio se aleja de aquellos análisis gramaticales (Mitchell 1980) y explora, en cambio, cómo las imágenes mismas actúan en la vida de estas familias.

\section{ESCONDER, QUEMAR Y CALLAR. LA LABOR DEL CUSTODIO}

Las imágenes que conforman la decoración de una casa están regidas por una economía de la mirada que, practicada generalmente por la red social femenina ${ }^{6}$, gestiona lo que se puede mirar

6 Bourdieu ya apuntaba a cómo el papel de la mujer en la gestión de la fotografía está vinculado a las prácticas sociales que venía desempeñando. "La división del trabajo entre los sexos reserva a la mujer la tarea de mantener las relaciones con los miembros del grupo que viven lejos y, en primer término, con su propia familia. Incluso mejor que la carta, la fotografía ayuda a la actualización perpetua del conocimiento mutuo» (2003: 60). 

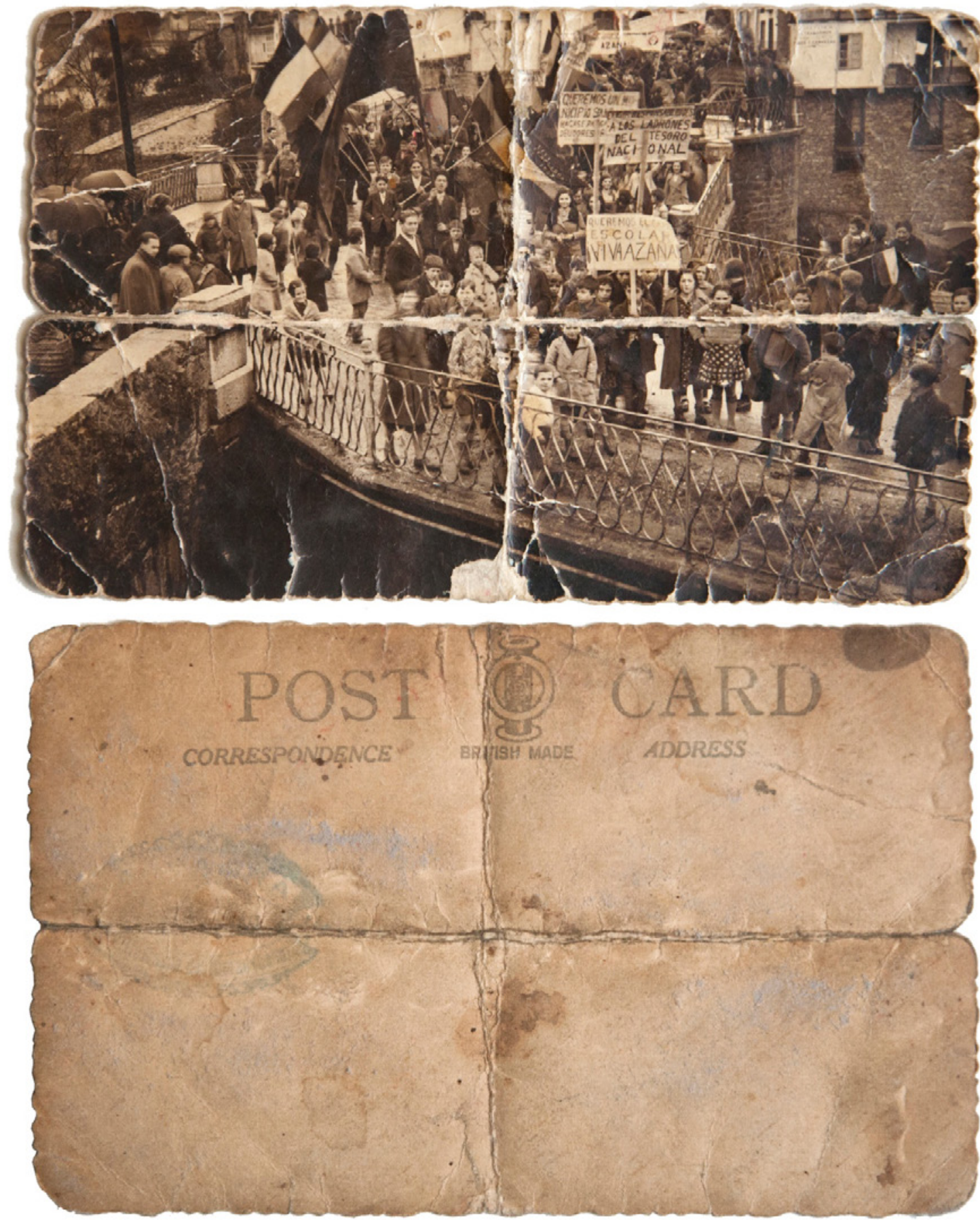

FIGURA 1. - Manifestación en Villafranca del Bierzo en 1932. Colección particular de Emilio Silva

en el espacio privado. Hay por tanto un conjunto de normas explícitas o implícitas que regulan qué cosas se exponen o cuál es el lugar destinado para cada imagen. Algo que observamos por ejemplo en la diferencia entre las fotografías o pinturas colgadas en el salón, el recibidor o el dormitorio, pero también entre aquellas que se guardan o se esconden. Las normas que definen lo que es visible dentro del espacio íntimo así como el acceso a esos materiales, no se articulan en función de lo que pueden ver las visitas, los que vienen de fuera, sino que crean un universo de sentido para los que la habitan dentro. Sin embargo en ese interior, no todas las personas tienen acceso a ver las mismas 
cosas. Hay una diferencia clara entre lo que pueden mirar unas y otras, y por tanto un contraste entre lo que los miembros de la familia saben de ellos mismos, algo que se acentúa en el caso de familias que transitan por un contexto de violencia.

El asesinato de Emilio Silva Faba cometido por un grupo de falangistas en octubre de 1936, provoca que su mujer tenga que reordenar en el interior de su casa las fotografías familiares que de él tenía. En un momento anterior, coincidente con la llegada del ejército sublevado a Villafranca y con la detención de su marido, Modesta lleva la purga de aquellos documentos que hacían referencia a la condición política de Emilio. Serán por tanto los objetos más comprometedores, por su posibilidad delatora, los que hay que borrar y eliminar con mayor urgencia. Es en ese momento cuando las imágenes se queman, se entierran o se introducen en la rendija de una pared ${ }^{7}$. Y son por tanto las dobleces en la fotografía de la manifestación, o la leyenda de una fotografía de Emilio con Azaña, las que encuentran en este momento su sentido fundacional.

«En mi casa siempre se ha vivido el mito de que mi abuelo tenía una foto con Azaña. Mi abuelo tenía una tienda muy grande de coloniales y un sitio de comidas. Y en una parada de una campaña electoral que iba hacia Coruña, Azaña para en Villafranca del Bierzo y luego se dio un paseo por el pueblo y... Esa foto mi padre me contaba que mi abuela la quemó. O sea el grado máximo de peligro [...] y mas cosas que quemarían».

Tras el asesinato del padre de familia, vendrá una nueva purga que tiene ahora que ver directamente con la ocultación del propio difunto. Imaginamos entonces a Modesta descolgando el retrato de su marido de la alcoba para esconderlo a partir de ese momento en el interior de una caja. Si la fotografía familiar «no es más que la huella de un protocolo social de integración destinado a sacar a flote a la familia» (Barthes 1989: 33), aquí esa función se invierte, pues es precisamente la imagen lo que problematiza sacar a flote al propio grupo. Uno de los ejemplos que evidencian esta purga será la evocación por parte del nieto de una cámara de

7 Es decir, si en la casa de Modesta habrá cosas que se ocultan a los miembros de la propia familia, hay objetos que además de ocultarse para ellos, también se camuflaban para la gente que pudiera entrar a la casa para hacer un registro. fotos que, arrinconada en el desván de su abuela, quedó como el vestigio de un tiempo anterior. "Mi abuelo por ejemplo tenía una cámara de fotos que trajo de EEUU, una Kodak de 1914 con fuelle. Lo cual debía significar que el debía tener su álbum fotográfico. En el pueblo se acuerdan mucho cuando vino con ella y con una máquina de escribir. Y la cámara todavía se conserva pero jamás nos ha dejado a nosotros en herencia una foto». Hacer desaparecer las fotos o quemar las imágenes de toda una vida, como así supone Emilio, tiene algo de eliminación de pruebas. Eliminación de un pasado que a partir de ese momento vivirá únicamente disimulando su existencia en los márgenes de la propia historia familiar. La desaparición de Emilio en el espacio público tiene una continuidad con su ocultación en el espacio privado. El asesinato activa por tanto en la casa de Modesta una nueva narrativa que, vinculada al disimulo y al silencio, excluye con las imágenes los relatos del marido.

\footnotetext{
«Jamás, jamás, nunca, nunca. O sea ni nombrarlo. Mi abuela murió en el año 1997 que tenía yo ya 32 años. Yo jamás la oí nombrar a mi abuelo. Una foto jamás. Y si estaban ahí mis tíos cenando, después de comer en la sobremesa. Empezaban a contar batallas de jóvenes y ella veía que rozaba o que se acercaba el tiempo de la posguerra o tal pegaba un manotazo en la mesa y no había más que decir, ahí se acababa la cosa».
}

Si tradicionalmente las fotografías expuestas en un domicilio instauran la memoria del grupo en los tabiques de la casa, en este caso y, para mantener esos tabiques en pié, hay que esconder y ocultar al antepasado disimulando lo ocurrido. Es decir, hay que intentar romper cualquier continuidad con el desaparecido para evitar con eso la continuidad de la violencia sufrida. En este sentido la supervivencia del linaje implica, bajo la percepción de Modesta, la eliminación de su memoria.

\footnotetext{
"[De las fotos que se salvaron de la purga] La más política es la que estaba más escondida, las otras no tanto. La que es de la manifestación está doblada porque estaba metida en una rendija en una pared, las otras están perfectas, en perfecto estado, o sea de mi abuelo han quedado dos fotos porque en la de la manifestación quien aparece es mi padre. Ahí he descubierto cuando me la escanearon a muy buena resolución a un tío mío con seis años asomando la cabecita entre dos chavales. Es el tío que visitó a mi abuelo a la
} 
cárcel, que es a quién le dio este anillo como para decir que se lo cargaban. Y las otras no se donde se guardaron pero no están dobladas, y son más grandes. O sea que esas no les daban tanta inseguridad. No hay nada de política en ellas».

El hacer como si nada hubiera pasado es precisamente el núcleo donde se vertebrará el relato familiar, tanto dentro como fuera de la casa. Si "no ha pasado nada» no hay ningún motivo para desatar odios o venganzas contra otros. Los efectos colaterales de esa ausencia no nombrada, cada uno los manejará como quiera o pueda, pero aquí, «pegaba un manotazo en la mesa y no había más que decir, ahí se acababa la cosa». Esos manotazos ponen el punto final a los tránsitos de un relato que quiere ir más allá de los límites impuestos por la propia casa. De esta manera observamos como la arquitectura del hogar ha quedado reordenada en torno a alguien que permanecerá silenciado, y que sin embargo supone el sentido que estructura determinadas prácticas familiares. Esos silencios ejecutados por la madre buscan por un lado eliminar de la boca de sus hijos relatos que puedan comprometerlos, pero sobre todo evitar la práctica en los varones de poder honrar la memoria del padre vengándolo. En ese sentido hay que entender que exponer al marido en una fotografía es exponer a los hijos a la venganza, y con ello a la posibilidad de destruir la casa. Las necesarias estrategias de protección de Modesta para mantener en pie su propio hogar, lo confirman situaciones como la de observar que su hijo trabajará con una de las personas vinculadas al asesinato de su marido, y que incluso en una ocasión le pedirá perdón por lo sucedido. Todo esto corrobora que toda precaución es poca ante lo que supone convivir con los asesinos del difunto.

«Mi tío Ramón trabajó de aprendiz en el taller de quien conducía el camión que se llevó a mi abuelo. Un día ese hombre cogió a mi tío y le dijo que a él le habían obligado [...] Le llamó para decirle que el no había participado en el asesinato, que le obligaba la Falange a hacer lo que hacían. Lo digo por el tono de miedo que tenía que tener mi abuela. Un hijo colocado con el que llevó el camión para asesinar a su padre. Claro en el fondo ver que sus hijos crecen y conocer a los asesinos y que en cualquier momento pueda haber ahí un choque, pues es un problema, es una amenaza que está ahí latente, incluso para los asesinos el ver que ya no soy un crío de nueve años, ahora te calzo una hostia o te espero a ti y te la devuelvo. O sea que siempre con ese miedo».

El disimulo también es un tipo de narrativa de la que se excluye o esquiva los elementos que tienen que permanecer silenciados. $Y$ el silencio se percibe en estos casos como el mejor integrador del grupo ${ }^{8}$, el integrador de una casa sostenida por una viuda con seis hijos y en un contexto inhóspito donde los asesinos de su marido son la autoridad del municipio. Cómo no imaginar en ese contexto episodios de una mujer presa por el miedo. «Un día le dio un ataque de ansiedad que no se movía y se pasó una noche tirada en la calle. Había toque de queda y mi padre no podía salir porque estaba la Falange [...] Mi padre tenía diez años y el pequeño seis meses. Entonces ella lo pasó allí. Hay algo de descontrol del dolor en todo eso, de no llegar a manejarlo», señala Emilio. "Ella tuvo tratamiento psiquiátrico. Era una crisis de pánico vamos. Porque incluso cuando les quitan todo lo que tienen en Villafranca se van a Pedeje, que es este pueblo pequeñito. Pero uno de los que mató a mi abuelo todavía pasaba con la escopeta de caza por delante de la casa».

Es precisamente en ese descontrol, en esos ataques de pánico donde se instaura un nuevo orden del que se hace necesario eliminar algunas partes. Estamos ante casas con memorias disimuladas cuyos cauces necesitan transitar por las orillas más seguras para mantenerla a salvo. Esas orillas serán precisamente la red social femenina, donde como señalaría Emilio, madre e hijas tuvieron un espacio donde sí hablaron de su padre. "Yo se que mi abuela habló con mis tías de mi abuelo, eso si lo se. Mi tía Carmela ya no vive, pero se que mi abuela con ellas ha tenido un espacio de...». La condición masculina excluía por tanto al joven Emilio de esos cauces de transmisión, algo que podemos ver en

8 Como señala el sociólogo Michel Maffesoli, «Nunca se hará suficiente hincapié en la función unificadora del silencio, que ha podido ser interpretado por los grandes místicos como la forma por excelencia de la comunicación. A pesar de que su relación etimológica se presta a controversias, puede recordarse que existe un nexo entre el misterio, lo místico y lo mudo; este nexo corresponde a la iniciación que permite compartir un secreto. El que este último sea anodino o incluso inexistente no resulta esencial. Es suficiente que -aunque sólo de un modo fantasmático- los iniciados puedan compartir algo» (1987: 65). 
la descripción que éste hace de la habitación de su abuela, una descripción que nos recuerda que estar excluido de determinadas redes femeninas, te excluye a su vez de transitar por determinadas estancias de la casa.

"Muy oscura, muy oscura. Tenía una ventana que daba a un corredor y siempre la recuerdo a oscuras, siempre a oscuras. Estaba en frente de la cocina, tenía una cama que había sido su cama de matrimonio. Tenía una cómoda a la derecha con un espejo y siempre la recuerdo a oscuras. Era un sitio al que yo no entraba, o sea era como una cueva. En estas casas de pueblo te pasas la vida en la cocina, o sea yo pasaba por la puerta de su habitación constantemente pero siempre estaba a oscuras. Su ventana daba a un corredor bastante luminoso que daba a una montaña que había allí y estaba siempre a oscuras. Y yo he dormido en casa de mi abuela siestas en todas las camas menos en la suya. O sea era como un sitio poco accesible por decirlo así».

Pese a los silencios familiares impera entreverado un recuerdo inquebrantable que es transmitido de manera periférica en pequeños grupos dentro de la casa. Estos cauces por donde transita la memoría del difunto se articula en tres tipos de grupos: madres-hijas, viuda-difunto y hijo-nieto. El primer caso es precisamente el de los espacios femeninos, donde de pronto la madre se permite el lujo de llorar frente a la hija. Así lo expresaba Carmela al señalar que si bien a su padre no lo conoció en persona, siempre vivió mucho el trauma de su madre. "Porque yo me acuerdo de que salía con las chicas y entonces como era la pequeña cada vez que regresaba a casa la encontraba llorando. Y me decía «te voy a pegar porque no me dejas ni llorar tranquila». Ella delante de nosotros tuvo una fuerza y una entereza tremenda, tremenda. Ella tenía 32 años cuando lo mataron y tenía 6 hijos» ${ }^{9}$.

El segundo grupo, el de la viuda-difunto, se objetiva en rituales individuales como el de acceder de manera solitaria a las imágenes de su marido que tenía escondidas, o en acciones futuras como poner el nombre del difunto en el panteón familiar cuando llegó la democracia. «Es el panteón del señor Silva Faba que lleva cincuenta y cuatro años

9 ARMH. 2012. "Exhumación de los trece de Priaranza". Disponible en <https://www.youtube.com/watch?v=CxB1kDkx4Ww>. Fecha de acceso: 26 dic. 2019. en una cuneta y que no sabemos si va a estar en un cementerio jamás. Pero ella sigue ahí, por un lado escondiendo y por el otro poniendo su nombre en el panteón» señalaba Emilio.

En el último caso tenemos las prácticas llevadas a cabo por el hijo primogénito del asesinado [Emiliohijo] en la transmisión a su descendiente varón [Emilio-nieto], consistente en la estrategia de poner el nombre del difunto a su propio hijo como forma de sellar un vínculo, de instaurar un origen. "Yo viví siempre con esa especie de presión en el fondo, ¿no? Siempre he sentido ese peso y siempre he tenido ese interés desde pequeño por cosas de mi abuelo, por papeles por [...] siempre subía al desván». Ese peso de la memoria, ese legado que convertiría a Emilio en el tercero de una saga ${ }^{10}$, lo une a un antepasado misterioso que sólo conoce de manera fragmentada, de los relatos puntuales de su padre, de lo silencios cargados de presencia en la casa de su abuela, o de aquellos objetos que quedaron en el desván y con los que establece un vínculo estrecho. Debemos recordar que el desván es ese sitio misterioso donde las correspondencias imposibles entre objetos en desuso, desconectadas de cualquier narrativa, abre sin embargo la puerta a la imaginación. A las narrativas que un niño construye rearticulando los escombros familiares. Un desván es en ese sentido un vertedero o un mundo lleno de posibilidades, y la fascinación por esa persona que tiene el mismo nombre que él, lo lleva encontrar en ese espacio un vínculo secreto. «Mi abuelo estaba [...] o sea lo que había de mi abuelo estaba en un desván que era: una pesa de su tienda, unos papeles con un sello de su tienda La Preferida, dos o tres participaciones de lotería».

«Mi padre tenía una obsesión porque heredara su apellido, era como una cosa obsesiva. Tuvieron tres hijas, nací yo, tuvieron otras dos a ver si aparecía otro [...] Y yo cuando comencé a firmar, que tenía once o doce años, yo firmaba como Emilio Silva III. Entonces yo, con ese nombre, el nombre de mi padre, con el nombre de mi abuelo, siempre tuve mucho interés en mi abuelo. $\mathrm{Mi}$ primera firma era Emilio Silva III, como si formara parte de una saga. Mi padre tenía cierta obsesión

10 Los Emilio Silva que componen la saga serían: Emilio Silva Faba, Emilio Silva Santín y Emilio Silva Barrera. Por esta razón, el último Emilio de la familia firmaría como Emilio Silva III. 
con eso, y yo viví siempre con esa especie de presión en el fondo. [...] Y la firma yo creo que es la mejor muestra del peso de eso, éramos una dinastía de Emilios Silva».

Para Emilio, su nombre además de un peso es la explicación a la distancia que su abuela siempre tuvo con él. Pues que el hijo de Modesta, le ponga a su hijo el nombre del difunto, el mismo nombre de aquel que ha querido ocultar, revela una estrategia inversa a la que ella trataba imponer, como si perdiera el control con algo que no puede controlar y que nota que se le escapa. Así lo explicaba Emilio: «Incluso puedo pensar que en esa relación de heredar el nombre yo también podría ser algo de difícil manejo. O sea ella pone a su hijo Emilio cuando su marido está vivo. Su hijo me pone a mi Emilio cuando su marido lleva treinta años muerto. De alguna manera para ella tenía que ser una cosa [...] no se si inconscientemente pero algo le podía afectar».

Emilio no conocerá el rostro de su abuelo hasta que tiene veinte años, momento en que se le revelan las imágenes ocultas de la casa. En esa mayoría de edad, necesaria para poder acceder a los secretos de la familia, el padre le muestra por primera vez la fotografía de la manifestación. Aquella donde él aparece con la pancarta que dice "Queremos un grupo escolar iViva Azaña!». La imagen revela un contexto insólito para Emilio, algo que le provoca una nueva fascinación que tiene que ver con la posibilidad de escudriñar el fragmento de una época desconocida. Una época que miraba a través de esa instantánea donde aparece su padre, su tío... «y la fantasía siempre de que hay alguien asomándose por la ventana» de la tienda de su abuelo». Pero esa mayoría de edad, es sobre todo el momento de descubrir cómo era su abuelo a través de dos fotografías: una de estudio tomada en Nueva York y la imagen de la boda.

"Yo nazco en el 65, y sería en los ochenta cuando veo las fotos de mi abuelo. Una estaba hecha en un estudio en Nueva York, y él la mandó a la familia. Era la típica foto de emigrado, de mira que bien me va y manda una foto a la familia. $Y$ luego otra foto que salen ellos en su boda. De mi abuela y mi abuelo el día de su boda. Y no hay más fotos. Todas las tenía mi abuela escondidas».

La práctica de ocultar a la persona que ha sido asesinada tiene un efecto contrario al esperado, pues es en realidad una forma de subrayar el asesinato. O dicho de otro modo, si eliminar supone borrar rastros, "esconder significa dejar huellas» (Benjamin 2012: 138). En ese sentido vemos que en la casa donde el disimulo impera, la relación con aquel que no se nombra es si cabe más estrecha. Esa relación no se puede dar sin embargo cuando todo el grupo está presente, sino que transita de manera aislada entre algunos de los miembros (madre-hija, esposa-marido, padre-hijo o nieto-abuelo). Asistimos por tanto a un desplazamiento del desaparecido del lugar de autoridad hacia los márgenes, alejándolo de los espacios donde se solidifica la historia oficial de la familia. Esa marginación empuja al antepasado hacia el ensueño o el enigma donde una fotografía desaparecida se convierte en leyenda. $Y$ no es por eso casual que años después Emilio utilice la ficción de una novela para intentar dar forma a su pasado, un relato imaginario que desde niño le había permitido acercarse a la historia familiar a partir de los vestigios a los que tuvo acceso.

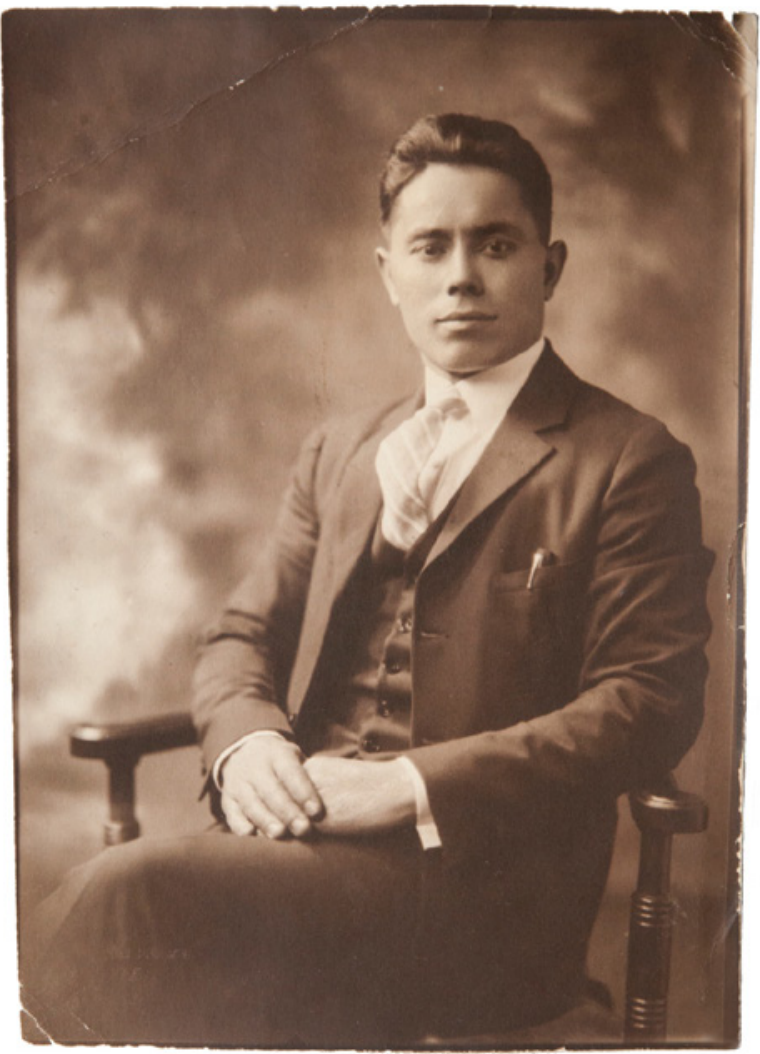

FigurA 2. - Emilio Silva Faba. Colección particular de Emilio Silva. 
Del desaparecido no se habla fuera y tampoco se habla dentro, y cuando se revela en el espacio íntimo lo hace siempre de manera aislada. Esto muestra el éxito de la estrategia de Modesta, que no es otro que desarticular incluso para los miembros del mismo grupo una memoria problemática, una memoria cuyo silencio la hace más íntima y enigmática a fuerza de volverla menos familiar y oficial. En esos casos, parece como si la intensidad pública que los relatos familiares pudieran tener, bajaran de tono al esparcirse entre las prácticas privadas de sus miembros, y eso evitara darle importancia, tenerla presente, oficializarla, encontrar un eco fuera, o ligarse vitalmente a un relato pasado que se enarbole como arma o como cuchillo vengador.

Estamos por tanto ante una economía de la mirada que, organizada por la madre, oculta a los miembros varones la reactualización de la memoria que les habla de un origen. El disimulo es percibido aquí como una práctica de supervivencia, como un intento desesperado por mantener en pie una casa que puede ser destruida por sus propios varones si no se dan las instrucciones precisas. $\mathrm{Y}$ las instrucciones consisten en encubrir la condición, en parecer normales. Es esa la manera de intentar desechar el estigma público en la integración social de la familia. Esa narrativa disimulada no es sin embargo algo temporal, sino que es una práctica que se aprende y se hereda, y que en el caso de Emilio (padre) la veremos activarse años después en la decisión de llevar a sus hijos a un colegio del Opus Dei.

«El camuflaje llega hasta que yo estudio en un colegio del Opus y mis hermanas en un colegio de monjas. Mis padres en los años setenta jamás fueron a misa. Y yo vivía en un sitio de gente de pasta del Opus, y mis padres eran los únicos del portal que no iban a misa. Pero nosotros estábamos en un colegio de orden que nunca entendimos, pero que sólo se podía leer desde el punto de vista de parecer normales. Estábamos en una operación de camuflaje de toda la familia, de no parecer. Luego he ido yo a la enseñanza pública. Pero hasta el 79 yo he estado estudiando en un colegio del Opus».

Estas estrategias de camuflaje comienzan a desarticularse al final de la dictadura, pero sobre todo cuando muera la persona que las compuso, pues ella las continúa practicando incluso durante la democracia. Es decir, la construcción del panteón familiar con el nombre y los apellidos de su marido en los años ochenta, que busca compensar con la exposición del nombre la ausencia del cuerpo en el cementerio, es una práctica que convive con el mantenimiento del disimulo en su propia casa. «Mi abuela murió en el año 1997 que tenía yo ya 32 años. Yo jamás la oí nombrar a mi abuelo», señalaba Emilio.

\section{DE FUSILADO A DESAPARECIDO. EL CAMBIO DE SENTIDO EN LA FOTOGRAFÍA}

La muerte de aquellos miembros del grupo, percibidos como custodios de la memoria familiar, produce una redistribución entre sus descendientes de las funciones y objetos que poseía el difunto. Será la muerte de Modesta, a mediados de los años noventa, lo que posibilite una reactualización del relato que ella sostenía. De la misma forma que tras el asesinato de Emilio en 1939 ella cambió la ordenación de los objetos que podían ser mirados en el interior de su casa, estableciendo con ello una diferencia entre relato soterrado y relato público familiar, ahora la muerte misma de Modesta supondrá el final de aquel que ella impuso. El fallecimiento dispara entonces la narrativa de unos objetos que pueden ser rearticulados en otro relato. Y aquí el patrón de género es fundamental para entender dónde y de qué manera pueden llevarse a cabo prácticas con las fotografías que son heredadas por los descendientes.

A partir de este diagrama observamos el itinerario de las fotografías entre los integrantes de la familia. El seguimiento a las copias originales nos permite evidenciar el diferente acceso de los miembros de un mismo grupo a sus propias imágenes ${ }^{11}$. Tras la muerte de Modesta sería el hijo mayor quien heredaría los objetos que quedan del padre. «En la zona del Bierzo siempre ha habido una cosa de mayorazgo» señalaba Emilio, "por el cual las cosas de mi abuelo le correspondían a mi padre: la cámara, el anillo, el reloj que lo tuvo un tío mío pero porque era el pequeñito. Éste tío fue al único que

11 Asumiendo la variable del tiempo y la activación de la fosa, se podría hacer un segundo nivel de análisis con el que explicitar el tránsito de las copias que hagan los familiares a partir de las imágenes originales. 


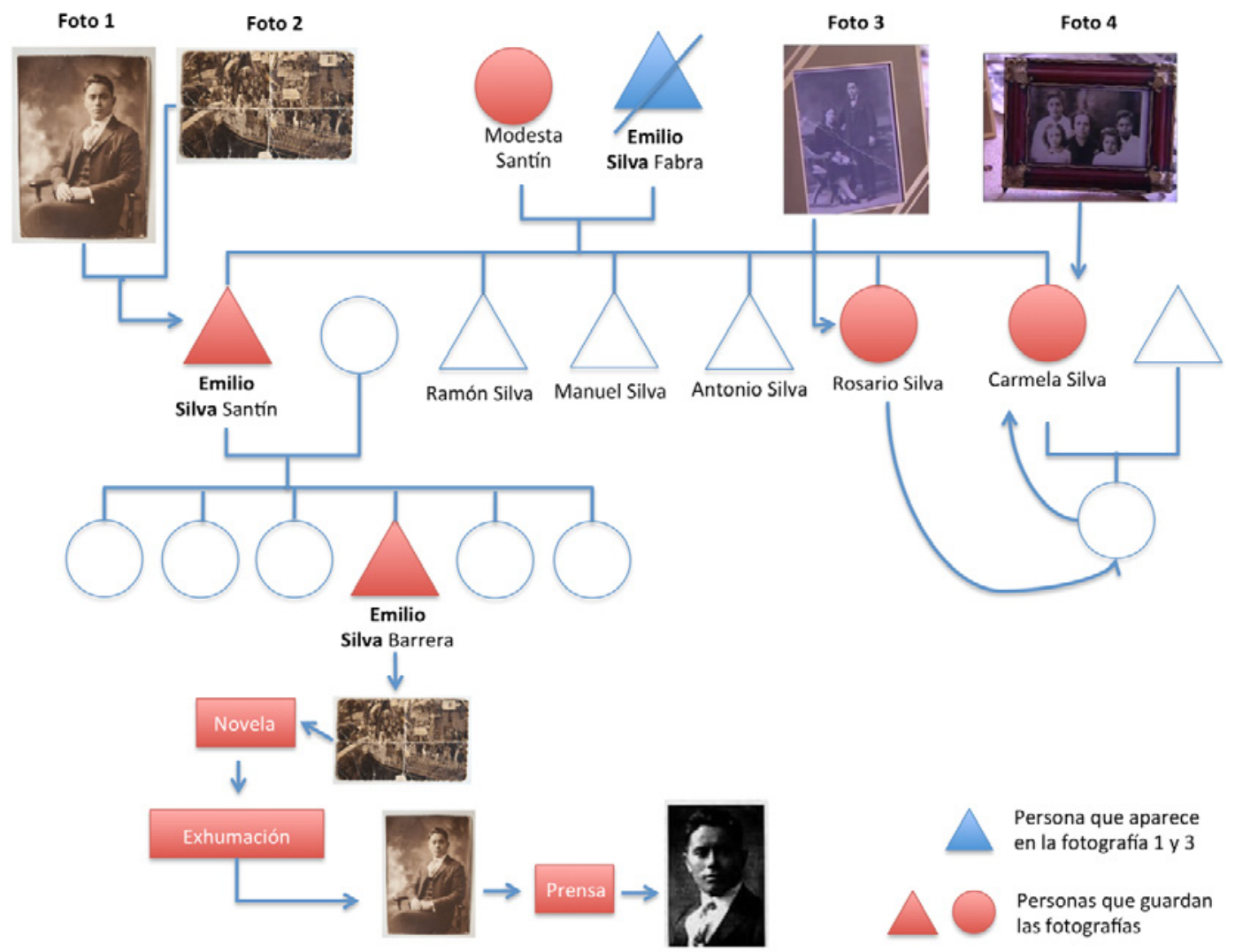

FIGURA 3. - Esquema de genealogía fotográfico. Elaboración propia.

dejaron entrar a la cárcel a verle la tarde que estuvo detenido, y cuando salió sacó el reloj». Más allá de a quién le toquen comúnmente las pertenencias en la redistribución familiar de la herencia, la propia biografía de la familia puede desplazar en ocasiones el destino esperado de los objetos entre los herederos. De hecho este comentario sobre la persona que tiene el reloj, intenta justificar el desplazamiento de un objeto que a priori debería de estar en la casa del primogénito.

Esta reflexión sobre la herencia indica que la posición que cada miembro ocupe dentro del grupo podría explicar una parte del tránsito generacional de las imágenes. Sin embargo no podemos olvidar que hay un claro marcador de género en este tipo de herencia. Los papeles de la memoria en los ámbitos familiares con toda probabilidad, salvo casos, han sido desempeñados por las mujeres ${ }^{12}$.

12 Uno de los aspectos interesantes que tiene en ese sentido este mensaje materializado, llamado fotografía, es que va asociado siempre con la palabra. Es decir no se hereda sólo el objeto sino con él la transmisión de un relato.
La reactivación femenina de las fotografías en el espacio doméstico determinará por tanto que sean ellas y no los varones las herederas comunes, pues son ellas las que "hacen casa», las que con las fotografías cuentan y recuentan quien es la familia. Si Emilio (padre) se queda con una imagen de su padre por tratarse del primogénito, y por llamarse como él, el resto de fotografías serán heredadas por la hermana mayor. Entre ellas se encontraría la fotografía de bodas de su padre Emilio. Observamos por tanto que no son todas las hijas las depositarias de las imágenes, sino sobre todo aquella que asuma la función de custodio de la memoria familiar. En este caso será Rosario quien la guarde, pues además fue la única de las hijas que pudo conocer a su padre.

El desplazamiento de las imágenes tiene además un marcador social, que recuerda que aquellas personas que aparecen en las fotografías son las posibles depositarias de esa herencia. Aparecer implica poseer. Es el caso de la imagen de la manifestación que se quedará Emilio, o aquella de la madre fotografiada con cuatro de sus hijos que se 


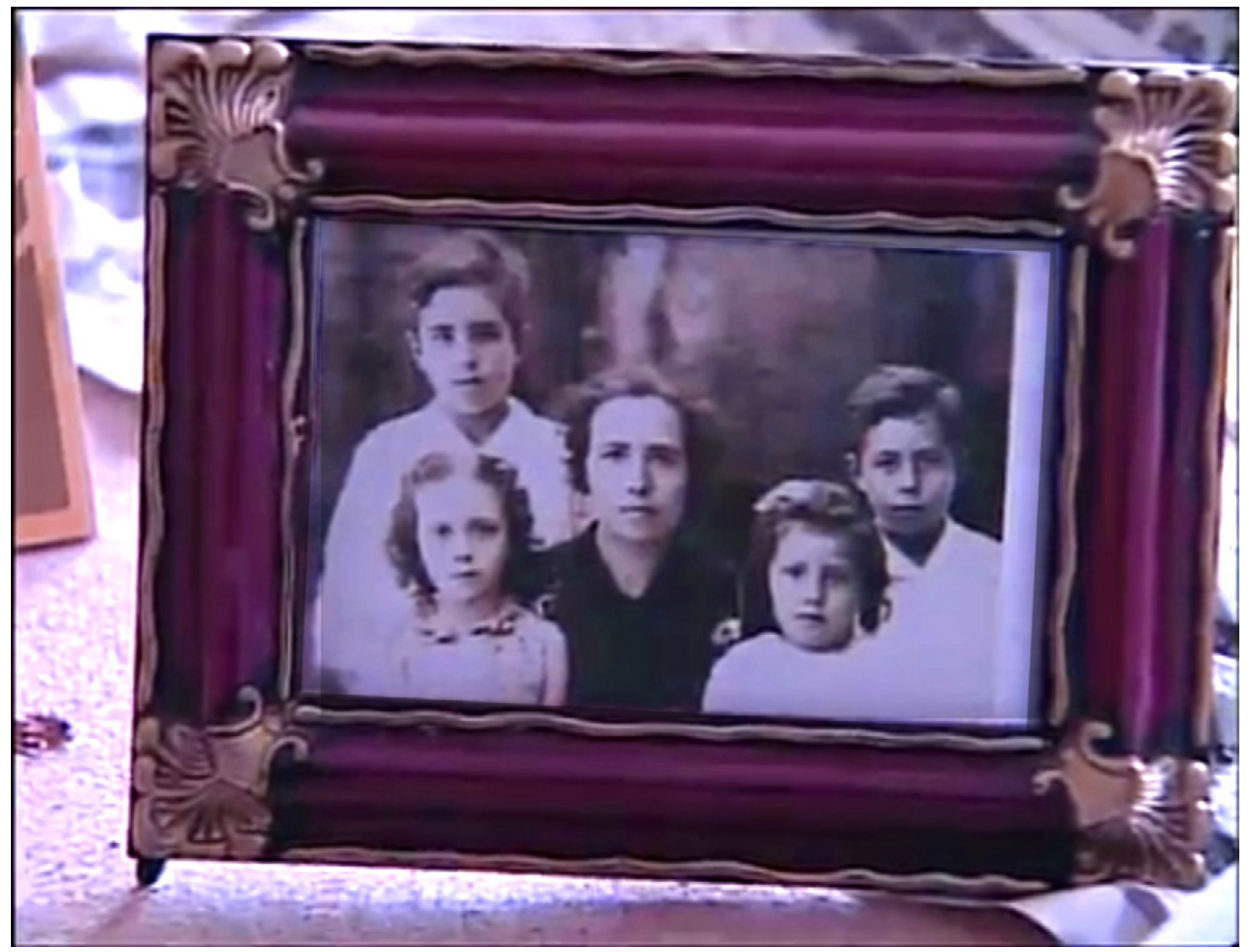

FIgURA 4. - Modesta Santín y cuatro de sus hijos. Fotograma de entrevista realizada a Carmela Silva.

quedará la hermana pequeña ${ }^{13}$. Una vez repartidas, observamos las diferentes prácticas que se llevan a cabo en la incorporación de las imágenes a la narrativa que cada casa impone. Esto es algo que se ve por ejemplo en la comparativa entre los usos que Emilio y su hermana Carmela hacen de las imágenes.

«Mi padre me las enseñaba siempre de una caja que tiene que estar en el trastero, donde había cientos de fotos desordenadas además, es decir con todo lo que tiene de ir cogiendo tacos e ir viendo a ver que aparece. Allí estaba la de mi abuelo, pero nunca colocada en ningún sitio. Yo la debo tener en una caja de por ahí que no se cual es, tampoco las he puesto. Mi tía en cambio si tiene alguna enmarcada. Esa de la boda que era una copia... si la tiene enmarcada. De hecho sale en ese video y enseña las dos fotos, las llevó con su

13 Aquí están funcionando varias variables, la de ser mujer, la de aparecer en la imagen y la de cierto reparto entre hermanas. marco. No enmarcadas para el momento, sino que las tenía así» ${ }^{14}$.

En estas prácticas observaremos un claro marcador de género, pues si las mujeres son las que heredan las imágenes es porque saben utilizarlas. Son ellas quienes tradicionalmente han desplegado una serie de usos domésticos que van desde la evocación de relatos a la enmarcación de la fotografía. Enmarcar una fotografía podría parecer un acto simple, pero ese pequeño gesto revela la instauración de un relato familiar oficial en el interior de la casa, un relato que indica a quien allí habita o transita, cual es el

14 Emilio hace referencia a una entrevista que le hicieron a Carmela en el laboratorio que instaló Francisco Etxeberría en la exhumación de Priaranza del Duero. Allí lleva dos fotografías: una reproducción enmarcada de la fotografía de boda de Emilio y Modesta, y una fotografía original, también enmarcada, de Modesta junto a cuatro de sus seis hijos. ARMH. 2012. "Exhumación de los trece de Priaranza". Disponible en <https://www. youtube.com/watch?v=CxB1kDkx4Ww>. Fecha de acceso: 26 dic. 2019. 
origen y la memoria del grupo allí representado. La decoración en una casa nunca es aleatoria, y en este caso el enmarcado de la imagen descubre en realidad el carácter anómalo o disimulado de las prácticas de la madre. Pues lo que en un sitio se expone de manera permanente, en otro permaneció siempre ocultado. La narrativa de la nueva casa instaura una rearticulación del pasado, de una situación que alejada del peligro puede conformarse ya sin disimulos. "Que mi abuela no colocara las fotos de su marido en ningún sitio visible de la casa», señalaba Emilio, «también era una operación de disimulo. Porque una foto también es una pregunta. $Y$ hoy llega no se quien que ya lo sabe, pero igual llega mañana no se quien que no lo sabe y pregunta por ese de ahí»

La condición masculina de Emilio lo distancia de las prácticas fotográficas domésticas, pues no son en ellas donde encuentra el vínculo con su propio pasado. "Las fotografías en mi casa nunca han estado en un marco, siempre han estado fuera de él. No ha habido una tradición de exponerla». Es decir, las imágenes que habían permanecido escondidas durante años y que después su padre hereda, se siguen conservando en una caja. La línea paterna no propone una nueva articulación de las fotografías heredadas en el espacio privado, porque la economía de la mirada doméstica es una práctica activada tradicionalmente por las mujeres. Esto nos permite pensar la diferente manera de relacionarse con una imagen que está expuesta o que está guardada entre documentos. Pareciera que el tratamiento de esa fotografía en un cajón lo dota de una aspecto informativo, más que el afectivo que supone la contemplación en la pared. Pero hay algo más, la enmarcación de las imágenes revela una transmisión que había permanecido soterrada, un diálogo privado entre madre e hijas que se hace ahora visible en las casas de éstas pero que en el fondo ya existía. El relato fundacional que en otro tiempo se construyó entreverado entre mujeres, ahora es un marco de referencia visible para los nuevos integrantes del grupo.

Tras la muerte de su abuela, el nuevo espacio donde su nieto rearticula el vínculo con ella, no es en prácticas desarrolladas en el espacio privado, sino en el espacio público. Asistimos por tanto a un desplazamiento de aquella fotografía que permaneciera durante años escondida, para ser ahora la portada de una novela. Como señalábamos más arriba, no es casual que sea el género de la ficción el elegido por Emilio. En su elección se observa una traslación del tipo de relatos que escuchaba a su padre en la casa, aquellos que lejos de pertenecer a la imagen oficial de la familia, habían sido preservados en los márgenes. En ese sentido más que historias, siempre fueron leyendas o incluso ensueños. La novela le permite recolocar aquellos vestigios en una práctica que comenzó con las visitas que de niño hacía al desván, pero que ahora tomarían cuerpo en un relato imaginario donde la fotografía más secreta de toda su casa ocuparía el centro de la historia.

La reactivación del pasado objetivada en los nuevos usos de las imágenes familiares en manos de hijas o de nieto, tienen algo de continuidad con la manera en que desde niños se relacionaron con el ser ausente. El horizonte de lo que se puede hacer con las imágenes nos recuerda que no se puede entender la enmarcación de las hijas sin las prácticas soterradas de madre-hija, ni la relación de Emilio (nieto) con su novela sin sus visitas al desván. Todas esas prácticas aunque rearticuladas exigen un reconocimiento, exigen que algo de lo que uno ha sido permanezca en el centro mismo de las nuevas prácticas.

La imagen que fascina a Emilio, es un objeto cuya ubicación acentúa además su condición enigmática, pues de tan escondida que estuvo el objeto inscribió en su superficie las marcas de un secreto. La fotografía que atrae y anima a este hombre, es aquella donde se muestra a su padre portando una pancarta en una calle llena de niños, de banderas... con la tienda de su familia al fondo "y la fantasía siempre de que hay alguien asomándose por la ventana». Esta fotografía alberga en su interior los ingredientes precisos para disparar la imaginación, para querer introducirse en ella y resolver en ese viaje todos los secretos que muestra la apariencia. Mirar para Emilio la instantánea cuando ésta pudo mirarse, es pensar además en su propia vida, en los silencios de su abuela, en los disimulos de su padre...

En ocasiones, las fotografías son objetos que evocan un pasado enigmático, a quien el que mira está abocado a descubrir, como si activara en él una especie de búsqueda. Si la muerte activa la narrativa, la foto anima a la aventura. Y quizá por ello, halla que ver en esa capacidad de animación que tiene este objeto parte de la explicación del tránsito hacia la calle. «En este sombrío desierto, tal foto, de golpe, me llega a las manos; me anima y yo la animo. Es así, pues, como debo nombrar la atracción que la hace existir: una animación. La foto, de por sí, no es 
animada (yo no creo en las fotografías "vivientes"), pero me anima: es lo que hace toda aventura» (Barthes 1989: 50).

Si en otros casos, una instantánea doméstica suele estar sustentada por el grupo que la guarda, y son sus miembros quienes monopolizan y reactualizan el relato oficial de la persona representada, aquí la ocultación familiar del difunto construyó en realidad una imagen enigmática pero difusa. Por tanto será hablando con otras personas fuera de la casa donde completar o dar un sentido amplio a los objetos que hereda. Esas entrevistas que realiza Emilio y que en un origen buscaban entender el contexto de violencia vivido en la zona del Bierzo, lo sitúa en un espacio de posibilidades, no sólo para ambientar su novela sino de paso para preguntar por su propia historia.

Estamos por tanto ante cuatro variables que explican el tránsito de una imagen del espacio privado al público, el itinerario que desplaza la fotografía de los márgenes del relato familiar a la centralidad de un foro público. Esas cuatro variables son: la potencia "animadora» y evocadora de una fotografía (acentuada si cabe por la ocultación del objeto), la línea de parentesco y las prácticas asociadas a su género (público en lugar de privado), la rearticulación de la memoria familiar tras la muerte de su abuela (la posibilidad de incorporar otra narrativa), y la necesidad de escuchar otras voces que en la calle ayuden a completar la narración disimulada de su casa.

\footnotetext{
Me estaba documentando para esta historia que estaba escribiendo, entonces los fines de semana concertaba unas entrevistas [...] iba y volvía. $Y$ ese domingo quedé con Arsenio por la mañana porque me iba a llevar a ver a un guerrillero que había hecho la mili con él, y luego el me había localizado a otro hombre. Cuando estaba comiendo con Arsenio, este hombre me llamó y me dijo que no podía venir pero que me iba a escribir lo que me quería contar. Si en lugar de no venir hubiera venido, yo no hubiera hablado con Arsenio de la fosa de mi abuelo, ni hubiera ido allí.
}

La ausencia del entrevistado alarga la conversación con el que era amigo de su padre, y sin planearlo hablan de su abuelo, algo que desembocará en la búsqueda de la fosa. "Yo me adelanté mientras Arsenio me seguía, acompañado por un paisano que le hablaba de otras fosas que no habíamos visto. Cuando llegué al lugar encontré a un hombre detenido junto al desvío. Yo he dicho siempre que ese hombre estaba como esperándome. Y entonces le dije: ando buscando una fosa con 13 o 14 personas de octubre del 36 [...] y me señaló un árbol y me dijo debajo de esa nogal recrecida». EI encuentro con el lugar llevará a Emilio a desterrar la novela para comenzar a hilvanar un legado mucho mayor: la recuperación del cuerpo de su abuelo. Si fue la imagen de una manifestación de 1932 la que activa el interés por escribir un libro, frente a una fosa será el retrato de su abuelo realizado en los años veinte en Nueva York el que salga del domicilio para mostrar a la luz pública la imagen de la persona asesinada.

De entre todos los objetos que del ausente tiene la familia, la fotografía se alza como el elemento central de la restitución que supone este proceso. Debemos recordar que la ausencia del cuerpo acentuó el carácter ostensivo, que ya de por si tiene el retrato de un ser querido. Es decir, si la desaparición del cuerpo hace cada vez más borrosa la figura del desaparecido, la fotografía se encarga de recordarnos la medida exacta del cuerpo que tenía, de aquella mirada que sin la imagen uno terminaría olvidando. Por eso las familias eligen las fotografías, cuando existen, como lugar donde seguir hablando con los muertos, pues la nitidez del retrato se percibe como el lugar donde las conversaciones con el ausente son precisamente más nítidas, más transparentes, un camino directo hacia lo que ya no está (Moreno Andrés 2018). Emilio lleva a la fosa aquella fotografía que Modesta no eliminó, pues en el fondo aunque no la mostrara, deshacerse de ella hubiera supuesto deshacerse del único lugar donde estaba la presencia de su marido, una presencia con la que se relacionó de manera constante en prácticas individuales. Esto es algo que revela el diferente estado de ocultación de las imágenes, pues si la más comprometida tenía marcas, las otras estaban en perfecto estado. "Al final mi abuela con sus escondites o no escondites es la que cuida de esa foto también. Porque en realidad nadie puede decirle que no la tenga. Una foto con un fondo donde hay florecitas [...] no hay nada en ella que le puedan reprochar».

Desde el primer momento las fotografías ya estaban ahí. De hecho, cuando presentamos en septiembre del año 2000 la placa que íbamos a 
ponerles después de que abriéramos la fosa, allí colocamos dos o tres fotos. La de mi abuelo, otra de Enrique González Miguel, uno que le llamaban "el madrileño», y otra de Manuel Largo. Tres de los que yo sabía entonces que estaban en la fosa y que habíamos conseguido fotos de ellos. Estaban encima de la placa colocaditos. En ese sentido se activaron desde el primer momento. En el fondo tiene una cosa de prueba, una prueba de vida, una fe de vida. Era este. Existió. Como nunca se ha hablado, al final la única prueba de que hubiera existido, más allá de una acta de nacimiento, acaba siendo esa foto.

Frente a lo disperso de los "relatos soterrados», aquellos que solo podían ser revelados en los márgenes, la fotografía viene a exponer de manera categórica una existencia. Por eso se pondrán «colocaditos», señalaba Emilio en una expresión que da cuenta de la presencia que la imagen convoca. Esas fotografías serán los objetos con los que los familiares instauran el lugar donde están los restos. Activando además todos aquellos relatos que unidos ahora con el de otros familiares, y con el de los científicos ${ }^{15}$ que trabajen en la exhumación, empiezan a conformar una narrativa compartida. El hallazgo de la fosa y el inicio de la exhumación la complementa Emilio con la investigación sobre las otras personas que estaban en la fosa. Aquellas entrevistas que buscaban ser la ambientación de una novela, se articulan ahora para buscar otro sentido: encontrar pistas que ayuden a esclarecer lo ocurrido en ese lugar.

\begin{abstract}
Me acuerdo cuando fui a ver a Abelia. Me acuerdo cómo me abrió la puerta de la casa, era un fantasma. Yo le dije "vengo a decirte que hemos encontrado que tu padre está en la fosa", y ella me cuenta, cómo su abuela quiso desenterrarlo. Cuando la llamé, para ella fue una cosa impactante. Madrugó, se hizo 400 kms, llevó unas flores, llevó la foto y estuvo hablando con mis tías. Se conocían, que eso es también una de las cosas que pasa, se conocían pero nunca habían hablado de sus padres. Habían estado de jóvenes cosiendo, pero nunca sabían que sus padres estaban enterrados en la misma fosa. ¡Esta cosa de los silencios! ¡Cómo puedes tener una biografía tan unida por cosas y tan silenciada!
\end{abstract}

Las hijas de los asesinados revelaban en público algo que había permanecido oculto incluso entre

15 Para un estudio sobre la relación entre conocimiento científico y familiar consultar Aragüete-Toribio (2017) y Douglas (2014). los miembros de su propia familia. Frente al cuerpo, con la fotografía en la mano, la escena recuerda a la de un tanatorio, aquellos lugares donde el final del acontecimiento vital disparan la narrativa sobre el ausente. En este caso ese ritual se está haciendo a destiempo, más de sesenta años después del suceso. El espacio tampoco es el de esos funerales normativizados, sino la escena de un crimen. De todo eso se mezcla lo que frente al cuerpo se cuenta, una historia llena de silencios que ahora se explicitan públicamente y que buscan de manera constante, y en la boca de los otros, el orden que revele lo sucedido.

Alejado del relato novelesco con el que Emilio iniciara la búsqueda, el texto que a partir de ese momento escriba tendrá el formato de una noticia, concretamente la noticia de una desaparición. Hay una relación directa entre la profesión de periodista de Emilio Silva y la gran repercusión mediática que tendría la apertura de la fosa donde estaba su abuelo enterrado. Así lo señalaba: «Una de las cosas que ha influido es que yo soy periodista y si hubiera sido no se que, desconectado del mundo pero [...] yo inmediatamente me puse a intentar hacer ruido con el tema». Publicada el 8 de octubre de 2000 bajo el título «Mi abuelo también fue un desaparecido», el artículo instaura en España el concepto de "desaparecido" para referirse a lo que hasta ese momento las familias habían llamado "fusilados». Un concepto que como veremos a continuación exige una modificación de la fotografía que acompaña a ese relato.

\footnotetext{
Hablo con una periodista y le digo que estoy buscando a los familiares de los que están en la fosa con mi abuelo, y que me gustaría contar la historia de mi abuelo y lo que se de cómo lo asesinaron. Y estas son las dos imágenes que salen ahí. Esta foto es la foto central del reportaje, y luego esta foto de mi abuelo que la convertí en una especie de foto de carnet, la escanee, la recorté y salió una foto de carnet de mi abuelo. Lo mismo hice con la de Enrique González Miguel, que es otro de los que asesinaron con él.
}

Si un retrato enmarcado y ampliado en las estancias de una casa revela que la imagen necesita siempre transformarse para ocupar ese lugar, su exposición pública también implicará un cambio acorde con el espacio que la contenga. La publicación de la fotografía en un periódico acompañado de 


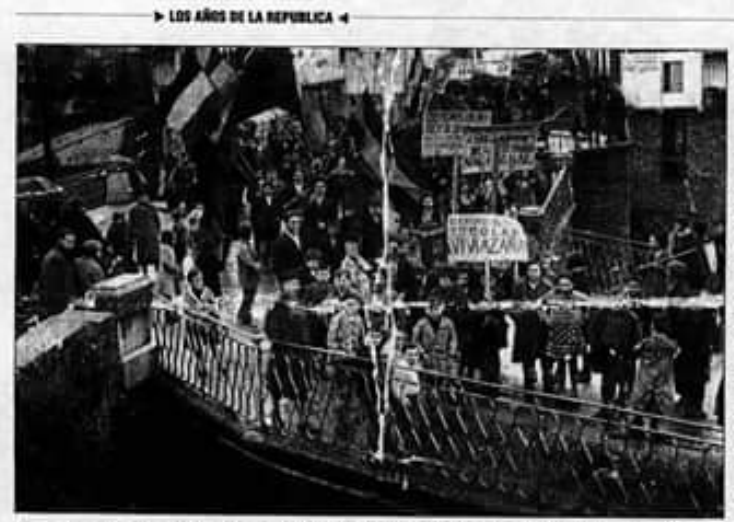

Mi abuelo también fue un desaparecido

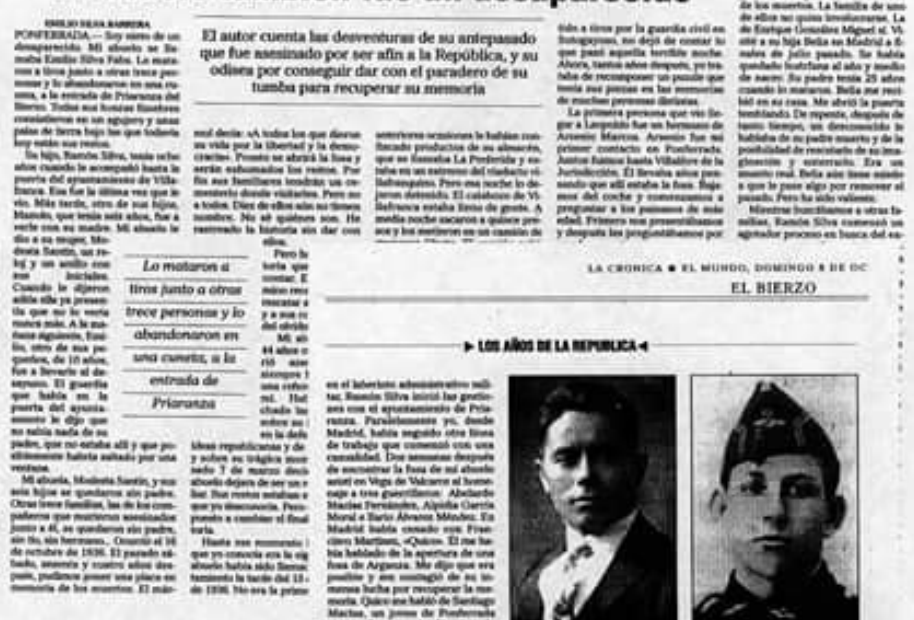

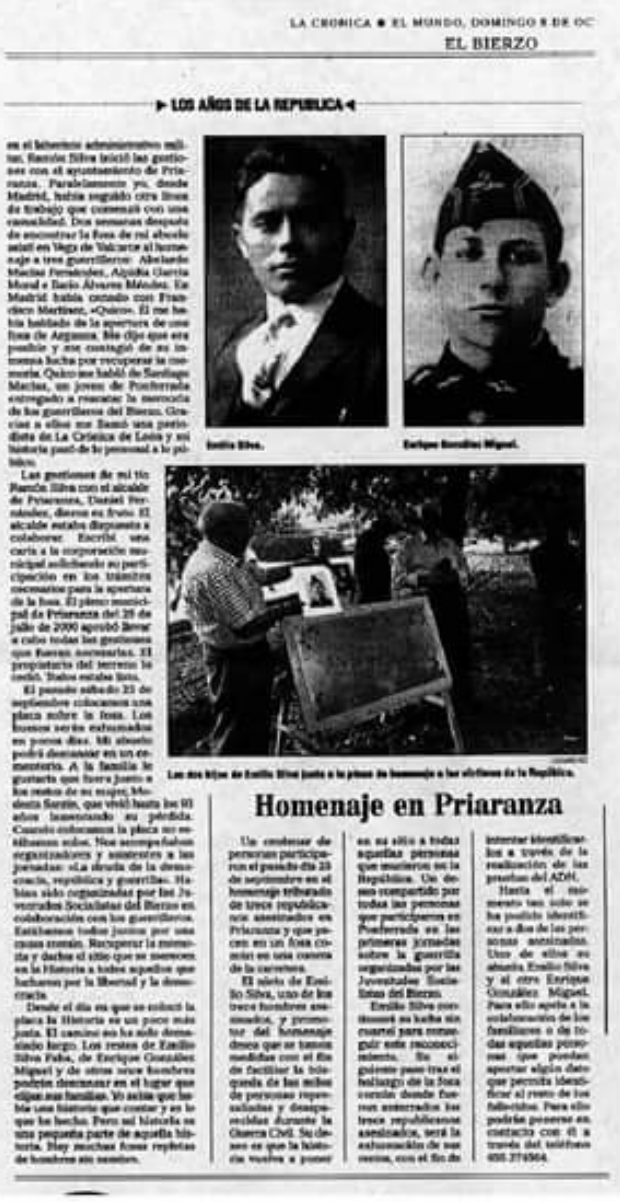

FiguRA 5. - Artículo «Mi abuelo también fue un desaparecido». Diario La Crónica de León, 8 de octubre de 2000

la historia del abuelo desaparecido, supondrá una modificación de la fotografía mediante un recorte de la copia original. Ese recorte o amputación del objeto no trata sin embargo de quitarle información sino sobre todo de añadirle otra. Pues el nuevo encuadre convierte el antiguo retrato de estudio en una imagen de carnet ${ }^{16}$. Esa transformación trata de imponer con la eliminación de una parte un revestimiento de autoridad. La autoridad que se sustrae de la tipología fotográfica de una persona cuando ésta tiene que incorporar su imagen en un documento oficial. El corte nos indica por tanto

16 Como señala Ludmila da Silva, la transformación en fotografías de carnets se produce como patrón en las fotografía argentinas que van asumiendo ese formato como modelo de protesta. "Recortar una foto para que se "asemeje" a una foto carnet, implicará compartir un sistema simbólico que ordena finalmente su contemplación y lectura» (2011: 10). que hay un intención de remarcar la existencia de ese individuo, una manipulación de la imagen cuyo propósito es convertirla en prueba.

Debemos recordar que el difunto ocupó lugares marginales no sólo en la calle sino incluso dentro de su propia familia. Eso hace que para evidenciar el asesinato y dar voz pública de lo ocurrido se necesiten romper ciertas barreras. Aquellas barreras con las que el régimen criminalizaba a las familias intentando cuestionar su propia legitimidad. En ese sentido la criminalización del régimen franquista se articulaba en la boca de las propias víctimas cuando éstas señalaban que «habían fusilado a tu padre y aun así te sentías culpable», o cuando comentaban frases del tipo «A quién le va a interesar que mataron a mi padre, dirán que si lo mataron es porque algo haría». Contra ese cuestionamiento público y contra los propios relatos familiares que fueron entreverados, Emilio expone 

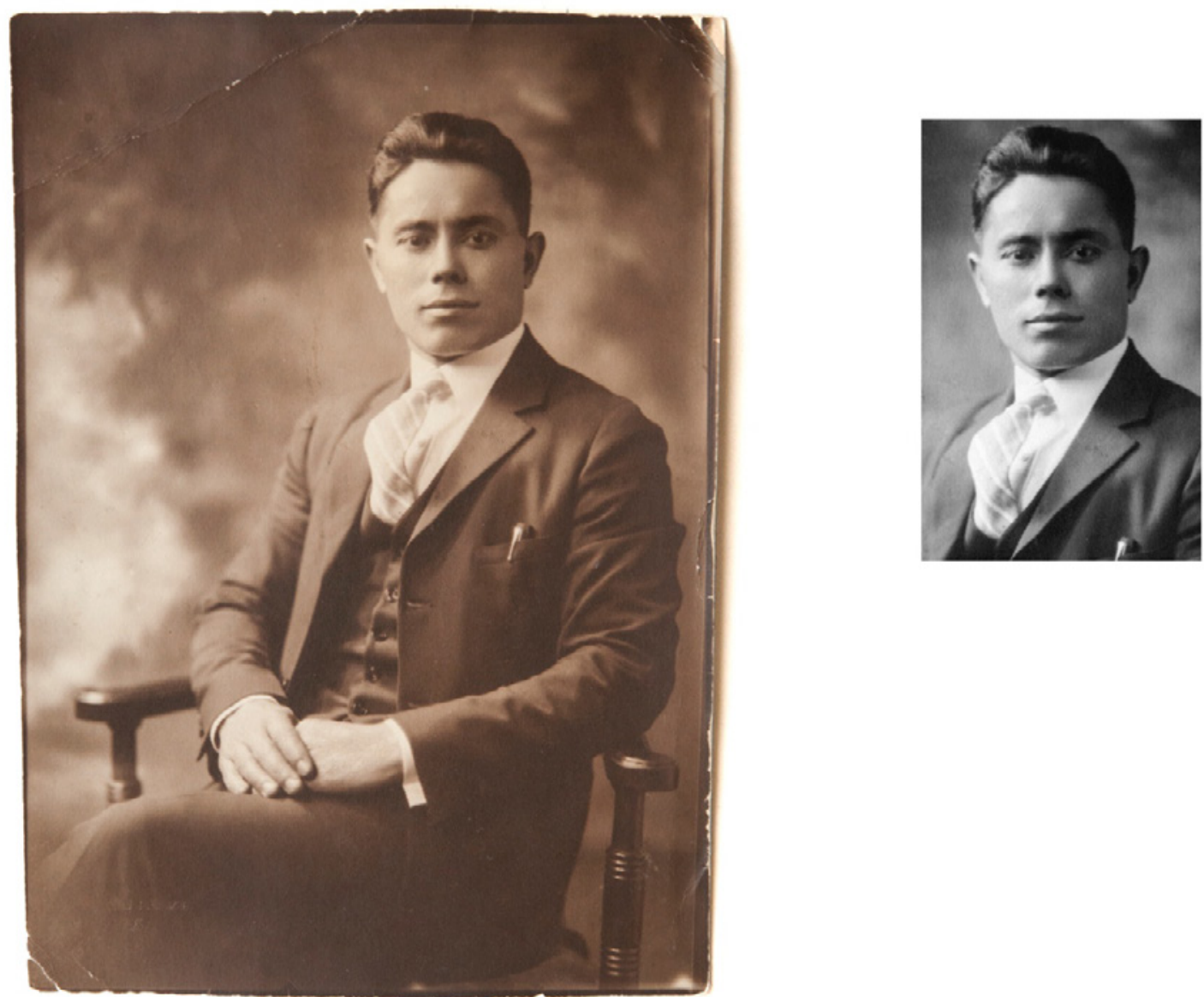

FIgURA 6. - Encuadre de la fotografía original de Emilio Silva Faba.

una fotografía que es la constatación inmutable de la existencia de esa persona. Convertir una imagen en una prueba, supone etimológicamente convertir la representación en algo honrado, en algo de lo que te puedes fiar. Eso es precisamente lo que cubre la fotografía de su abuelo con el recorte que hace de la imagen. Anteponiéndose a cualquier cuestionamiento posible, una foto de carnet es la evidencia exacta de que esa persona existió, pues está simulando la fotografía institucional con la que se acompañan a los documentos oficiales ${ }^{17}$.

17 Durante el régimen franquista, la desaparición de las personas en el espacio público contrastaba con la presencia de sus rostros en archivos policiales. Se trataba de incautaciones, en casas o instituciones, de fotografías donde aparecía el rostro del perseguido político. El destino de las imágenes era un archivo policial (Actualmente Centro Documental de la Memoria Histórica en Salamanca) donde se guardaba la información correspondiente a sospechosos o perseguidos políticos. Las fotografías se incluían en una especie de álbum fotográfico donde cada retrato incorporaba debajo del
Esta fotografía recortada por Emilio está asumiendo además el discurso internacional de los Derechos Humanos, pues se suma a la estética de aquellas manifestaciones del cono sur donde las pancartas reclamando el regreso de los desaparecidos son precisamente las fotografías de carnet de aquellos que el estado niega su desaparición. El uso de la fotografía de carnet, que en realidad tiene que ver con el

mismo, el nombre y el número de referencia de la documentación archivada correspondiente al individuo. El hecho de que todas las imágenes tengan el mismo formato nos recuerda a un origen común: fotografías pertenecientes a documentación oficial. Estos modelos visuales que responden a un prototipo pues suelen ser primeros planos en los que se resalta el rostro como la parte representativa y fidedigna del individuo. Esa concepción de lo fidedigno, por la cual la fotografía es considerada como representación exacta de la realidad, encuentra su legitimidad no en el valor indicial de estas imágenes, sino en la autorización estatal, que desde el nacimiento de la fotografía utilizó estos objetos como elemento de control y representación oficial de la persona. (Moreno Andrés 2018) 
mecanismo del estado para identificar al ciudadano, es subvertido para interpelar al estado desaparecedor pues la imagen evidencia que el estado identificador niega la existencia de esos sujetos. La oficialidad de la imagen tiene una relación directa con la oficialidad de una reclamación pública. Como si para establecer un diálogo con las instituciones se necesitara hablar en su mismo idioma. En esos emblemáticos retratos que portan las madres de la Plaza de Mayo, la representación originaria del ciudadano ha pasado sin embargo a asumir la noción de persona desaparecida. Desde un punto de vista estético, esa noción de desaparecido se asume convirtiendo casi cualquier imagen en fotografía de carnet. Incluso si la imagen pertenece a las instantáneas de unas vacaciones, se recortará para que asuma la misma voz, el mismo rostro en la protesta ${ }^{18}$.

Emilio se suma por tanto a ese recorte fotográfico que los familiares argentinos comenzaron a hacer con las fotos de sus desaparecidos. De esta manera inserta a su abuelo en el mismo régimen de sentido de aquellas protestas, que aunque ocurridas a miles de kilómetros mantienen una continuidad similar con el tipo de violencia política sufrida, porque a fin de cuentas su abuelo "también fue un desaparecido». Asumiendo la misma estética observamos que la fotografía de un fusilado se convierte por primera vez en España en la fotografía de un desaparecido. Esa influencia entre ambas estéticas hay que entenderla también a partir de la relación misma que Emilio tenía con la Agencia Argentina por los Derechos Humanos en España, y donde el título del artículo que escribe y la modificación de la imagen son la expresión misma de esa mediación.

Eso a mi me influyó mucho porque yo antes de encontrar a mi abuelo y de que se creara la asociación tenía mucha relación con el abogado

18 Así lo afirma Ludmila da Silva cuando señala que las imágenes "que originalmente no pertenecían al documento nacional de identidad, fueron recortadas de manera tal (como en el caso de Miguel Ángel Gárnica y Roberto Luis Cristina) para que se asemejaran y pudieran ser incluidas en la formalidad de un legajo. Fueron esas imágenes las que se usaron inicialmente para denotar su nueva condición de personas: de ciudadano, estudiante, profesora, obrero, etc. a la de desaparecido o desaparecida. Son esas imágenes, congeladas en el tiempo, las que por más de treinta años perduraron en el espacio público, en soportes como pancartas o banderas» (2011: 9).
Carlos Slepoy, con Carlos Castresana, con la Agencia Argentina por los Derechos Humanos en España que promovió los juicios de Argentina y metió en el viaje a Pinochet. Desde cuatro años antes de 1996 yo tenía mucha relación con ellos. Claro entonces eso me ha influido entre comillas a la hora de [...] De hecho el ADN que hacen de mi abuelo en Argentina lo trae el hijo de un exiliado argentino.

La vida pública que tendrán las imágenes en Argentina marcarán por tanto el patrón estético de las fotografías de los desaparecidos en España, no sólo en el caso de la prensa, sino también cuando unos años después el movimiento memorialista salga a la calle para denunciar la impunidad del franquismo. Ampliados los retratos a tamaño pancarta, el formato fotográfico asumido en esos casos será una consecuencia directa de los nuevos discursos que están asumiendo esas imágenes. "Nosotros hicimos muchas fotos», señalaba Emilio, "que la mayoría que hay son de la manifestación que hubo en abril de 2010, que es donde realmente cogimos 8 o 9 fotos [...] Hay una de Salvador Puig Antich, otra de Grimau, la fotografía de mi abuelo, otra del abuelo de Aníbal, del Bierzo, otra de una Miss Ponferrada ${ }^{19}$ que la asesinaron [...] O sea hicimos así como un mix y en el año 2010 hicimos doscientas copias plastificadas de esas fotos para la manifestación de la impunidad». Las fotografías individuales de esas primeras manifestaciones, con los años van a comenzar a aunarse en grandes pancartas. Un coro de fotografías agrupadas en una misma imagen nos recuerda actualmente que lo que comenzó casi por casualidad, se ha convertido en un movimiento. Los retratos que llegan a las fosas se introducen en esas pancartas asumiendo en ese tránsito el «encuadre del desaparecido". La presencia misma de sus rostros enarbolados por sus familiares son la cara visible de las protestas contra la impunidad del franquismo en las calles o en las plazas.

La fosa de Priaranza del Bierzo, abre por tanto una nueva etapa pública para la vida de aquellas fotografías que no esperaban ser expuestas. Los retratos desgastados, guardados en cajones o ampliados para colgar en el salón o el dormitorio, serán trasladados al lugar donde se encuentran los restos de los familiares. La fotografía que lleva a Emilio a encontrar el cuerpo de su abuelo se inscribe

19 Francisca Nieto. 


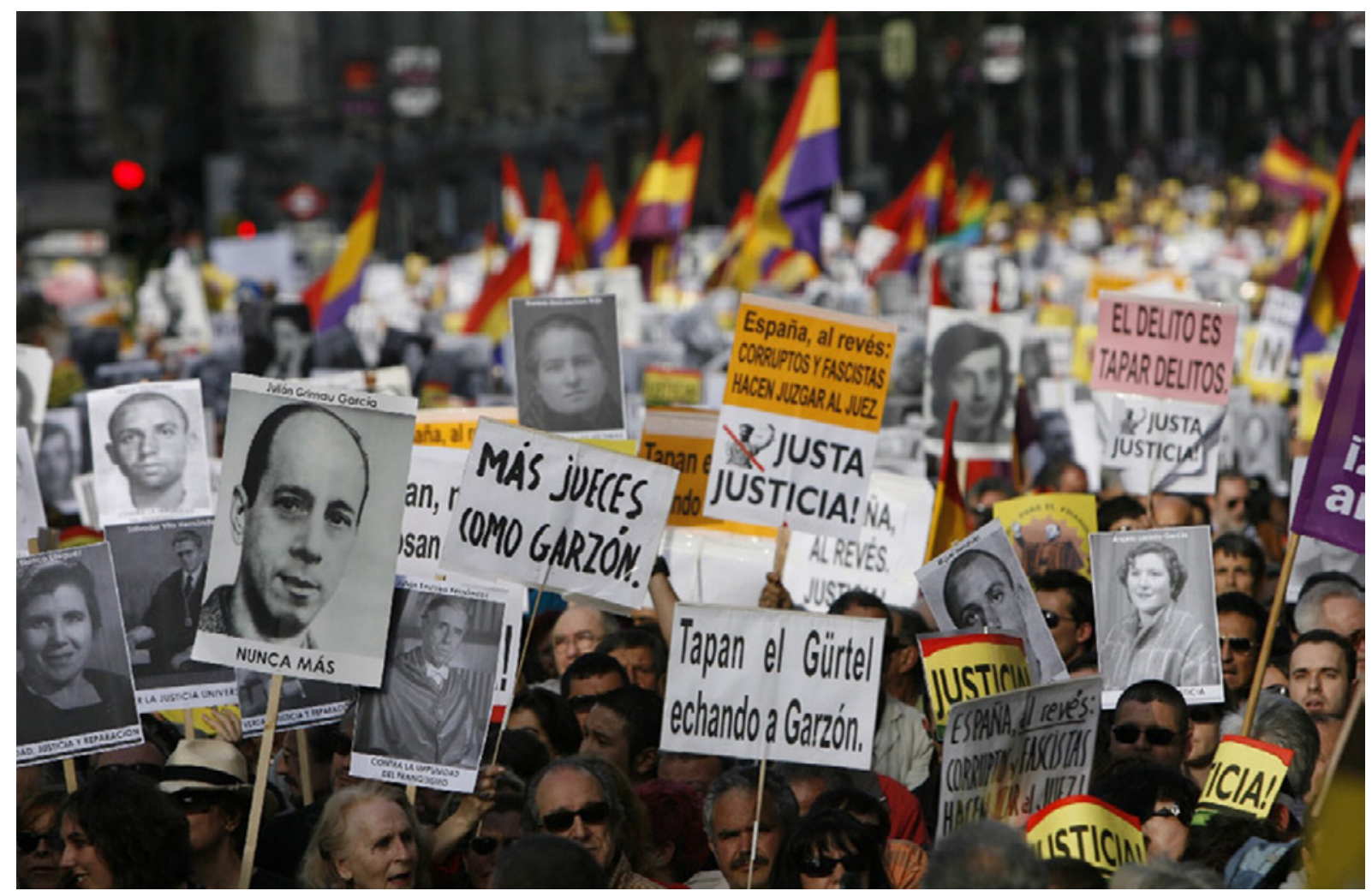

FiguRA 7. - Manifestación contra la impunidad del franquismo. 23 de abril del 2010. Fotografía: El País.

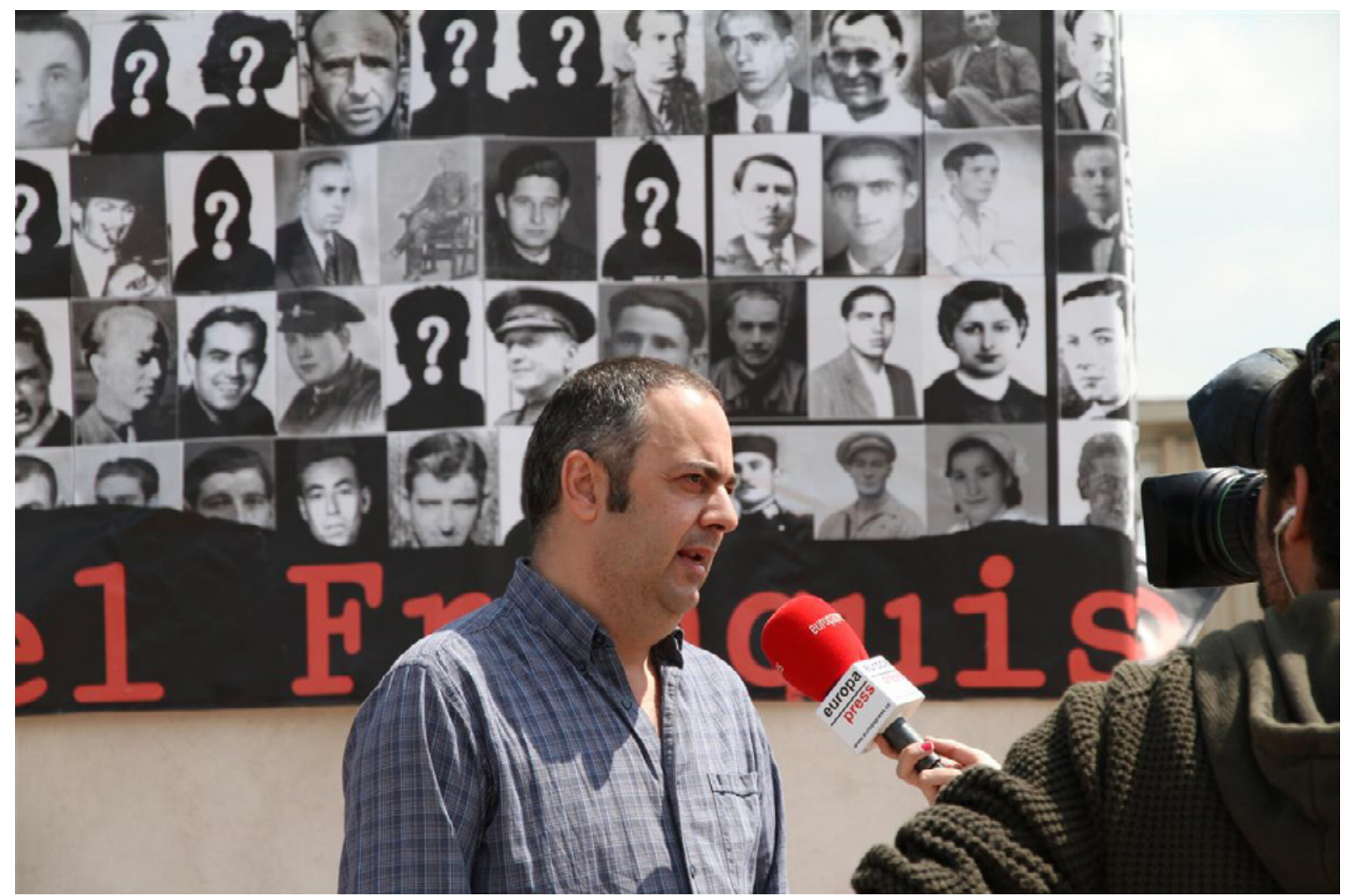

FIgURA 8. - Emilio Silva. Fotografía: Óscar Rodríguez. 
en los itinerarios familiares por donde circularon las imágenes en contextos de violencia. No se pueden entender sin la herencia, sin el binomio fotografíarelato, sin las prácticas femeninas y masculinas, privadas y públicas con las que los descendientes reordenan una memoria que ha quedado en suspenso tras la muerte del custodio. La práctica etnográfica pasa por constatar esos tránsitos en las marcas que sufren los materiales. Los recortes, encuadres, enmarcaciones o señales son las huellas que nos permiten entender la vida social de estas imágenes. A partir de ese momento las fotografías tendrán un sorprendente recorrido social irrumpiendo no sólo en las fosas sino también en los periódicos, homenajes, manifestaciones, charlas, libros, webs o redes sociales. En estos nuevos contextos las fotografías pierden su carácter puramente familiar, incorporando a ellos discursos políticos, humanitarios o históricos.

\section{BIBLIOGRAFÍA CITADA}

Appadurai, Arjun. 1986. The Social Life of Things: Commodities in Cultural Perspective. Cambridge: Cambridge University Press.

Aragüete-Toribio, Zahira. 2017. «Confronting a History of Loss in a Spanish Family Archive». History and Anthropology 28(2): 211-234.

Banks, Marcus y Howard Morphy (eds.). 1997. Rethinking Visual Anthropology. New Haven: Yale University Press.

Barthes, Roland. 1989. La cámara lúcida. Notas sobre la fotografía. Barcelona: Paidós Comunicación.

Benjamin, Walter. 2012. Denkbilder. Imágenes que piensan. Madrid: Abada.

Bourdieu, Pierre. 2003. Un arte medio. Ensayo sobre los usos sociales de la fotografía. Barcelona: Gustavo Gili.

Da Silva Catela, Ludmila. 2011. «Revelar el horror. Fotografía, archivos y memoria frente a la desaparición de personas».
Seminario Internacional Memoria, cultura y ciudadanía. Instituto de Historia de Nicaragua y Centroamérica de la Universidad Centroamericana, IHNCA-UCA.

Douglas, Lee. 2014. "Mass Graves Gone Missing: Producing Knowledge in a World of Absence». Culture and History Digital Journal 3(2): 1-12.

Edwards, Elizabeth y Hart, Janice (eds.). 2004. Photographs, Objects Histories: on the Materiality of Images. Nueva York: Routledge.

Ferrándiz, Francisco. 2011. "Autopsia social de un subtierro», Isegoría 45: 524-544.

Gell, Alfred. 1998. Art and Agency: an Anthropological Theory. Oxford: Clarendon Press.

Hirsch, Marianne. 2012. Family Frames. Photography, Narrative and Postmemory. Cambridge: Harvard University Press.

Ingold, Tim. 2015. Una breve historia de las líneas. Barcelona: Gedisa.

Kopytoff, Igor. 1986. "The Cultural Biography of Things: Commoditization as Process». En Arjun Appadurai (ed.). 1986. The social life of things: Commodities in Cultural Perspective. Cambridge: Cambridge University Press.

Maffesoli, Michel. 1987. "La hipótesis de la centralidad subterránea». Revista de Occidente 73: 63-75.

Miller, Daniel. 1987. Material Culture and Mass Consumption. Oxford: Blackwell Publishers.

Mitchell, W.J. Thomas. 1980. The Language of Images. Chicago: University of Chicago Press.

Moreno Andrés, Jorge. 2018. El duelo revelado. La vida social de las fotografías familiares de las víctimas del franquismo. Madrid: CSIC.

Poole, Deborah. 1997. Vision, Race and Modernity: a Visual Economy of the Andean Image World. Princeton: Princeton University Press.

Porto, Nuno. 2004. «Under the Gaze of the Ancestors: Photographs and Performance In Colonial Angola». En Edwards, Elizabeth y Janice Hart (eds.), 2004. Photographs, Objects Histories: on the Materiality of Images. Nueva York: Routledge. 